\title{
How to design Greenhouse Gas Trading in the EU?
}

\author{
Gert Tinggaard Svendsen* and Morten Vesterdal
}

\begin{abstract}
Summary:
A new and remarkable Green Paper about how to trade Greenhouse gases (GHG) in the EU has recently been published by the Commission of the European Union. This to achieve the stated $8 \%$ reduction target level. The Green Paper raises ten questions about how greenhouse gas permit trading should be designed in the EU before year 2005. These ten questions can be compressed into four main issues, namely target group, allocation of emission allowances, how to mix emission trading with other instruments and fourth enforcement. In the literature, there is a strong need to guide decision-makers and stimulate academic debates concerning the actual design of a simple and workable GHG market model for the EU. This model must take both economic, administrative and political concerns into account so that it is feasible in practice. Based on our findings, we therefore develop a policy recommendation concerning the future design of GHG permit trading in the EU.
\end{abstract}

JEL Classification: Q28, H2, H4

Keywords: European Union, energy policy, greenhouse gases, $\mathrm{CO}_{2}$ emission, permit trading design, Kyoto protocol, electricity sector.

\section{Acknowledgements:}

We gratefully appreciate the financial support from the Danish Energy Research Programme 1998. A previous version was presented at the $3^{\text {rd }}$ Danish Public Choice Workshop, November 30, 2001, in AKF, Copenhagen. We are grateful for the participants' comments. Special thanks go to Søren Varming, Peter Børre Eriksen, Poul Erik Grohnheit, Lise Nielsen, Peter Markussen and Erik Strøjer Madsen.

*Author to whom correspondence should be sent:

Gert Tinggaard Svendsen, Associate professor, PhD, Department of Economics, The Aarhus School of Business, gts@hha.dk, http://www.hha.dk/eok/nat/staff/gts_form.htm 


\section{1: Introduction}

The main focus of this paper is the application of emissions trading in European energy policy. The Commission of the European Union has published a 'Green Paper' about how to trade Greenhouse gases (GHG) in Europe, see CEU (2000a). Several books have dealt with emission trading in general such as Baumol and Oates (1988), Daugbjerg and Svendsen (2001), Dijkstra (1999), Svendsen (1998), Tietenberg (1985; 2000) and Wallart (1999). Still, no books have so far analyzed the recently proposed GHG market in the EU (Green Paper from 2000 by the EU Commission). Svendsen (1998) first suggested such a market scheme for GHG in the EU. However, this idea needs much more elaboration concerning design - this is the task here.

As the EU Commission notes, GHG emissions at European level have been increasing instead of decreasing. Without a reinforcement of current policy measures, the 'business-as-usual-scenario' is likely to result in an 8\% increase in year 2012 rather than the wanted 8\% decrease compared to 1990 levels, CEU (2000b). Therefore, the European Climate Change Programme (ECCP) was launched in June 2000 to bring together all relevant stakeholders to co-operate in the preparatory work of common and co-ordinated policies and measures to reduce GHG emissions. Emission trading will be the key policy in this setting (ibid).

Acknowledging the considerable interest in emissions trading in the climate change debate, the EU Environment Commissioner Margot Wallström said in March 2000 that "The Green Paper rightly advocates a prudent commencement of emissions trading that, if successful, can be extended. It must be understood that we are breaking new ground with such a system and we need to get it right from the start. However, I am firmly convinced that it can work if we put into place a strong framework with adequate controls. Then emissions trading will ensure that emission reductions will be made where they are cheapest and hence we will all benefit economically. It's not just about leaving things to market forces, but creating the necessary structures in which cost-effective incentives can exist" (CEU, 2000b). Thus, in order to guide decisionmakers and stimulate academic debates, there is a strong need for policy proposals concerning the actual design of a GHG market model for the EU. This model must take both economic, administrative and political concerns into account so that it is feasible in practice.

According to the Kyoto Protocol, the deadline for introducing such a market is 2008 . This dead-line may even be brought forward to the year 2005 according to the EU Green Paper which raises 10 questions about how permit trading should be designed. These 10 points can be compressed into four main issues, which we deal with in the following four sections, namely target group (questions 1-4) in Section 2, allocation of emission allowances (questions 5-6) in Section 3,3) how to mix emission trading with other instruments (questions 7-8) in Section 4, and the crucial issue of enforcement (questions 9-10) in Section 5. Based on these findings, Section 6 develops a policy recommendation concerning the future design of GHG permit trading in the EU. 


\section{2: Target group}

\subsection{Choice of pollutant and sector}

On one hand, we want to cover as much of total emissions as possible in the EU by our emissions permit system to achieve the $8 \%$ GHG target levels in a cost-effective way. On the other hand, we have to weight these benefits against monitoring and enforcement costs. Monitoring costs consist of the costs of measuring emissions. Enforcement costs consist of the costs of assessing whether there is compliance with the policy measure (whether permit rights are equal to emissions) and the costs of prosecuting violators. If the monitoring and enforcement costs required to keep violation within set limits for a source exceed the contribution of the source to reducing total abatement costs, it would be cost effective to exclude the source from control (ABARE, 1998).

Varming et al. (2000, 136-37) argue that an emission-trading scheme covering only $\mathrm{CO}_{2}$ emissions from the power and steam sector as being a sensible starting point. There are two main arguments in favor of $\mathrm{CO}_{2}$ as the target pollutant. First, $\mathrm{CO}_{2}$ emissions are by far the largest contributor to greenhouse gas emissions and will remain so for any foreseeable future. Second, $\mathrm{CO}_{2}$ emissions stems almost entirely from fossil fuel use and it is easy to monitor.

Next, the choice of the electricity sector as target group is based on five main reasons. First, the electricity sector is responsible for one-third of total $\mathrm{CO}_{2}$ emissions in the EU. In comparison, the industrial sector emit one-sixth and households one-fifth (EU 1999). Second, many low-cost $\mathrm{CO}_{2}$ emission reduction opportunities exist within the electricity sector. Third, the companies are relatively well-informed of the overall opportunities to reduce $\mathrm{CO}_{2}$ emissions in the market, which can work to encourage trading early on. Fourth, this sector is already tightly regulated. Fifth, it is, based on the US experience, crucial to start with a single sector to make the system as simple as possible.

The single focus on $\mathrm{CO}_{2}$ emissions from a single sector cannot be the final answer since emissions of other greenhouse gases and other sectors make a significant contribution as well. If emission reductions of the other greenhouse gases are to be achieved by applying other policy instruments, it is likely to result in differentiated treatment of different sectors and gases. From an overall efficiency viewpoint this is not preferable. However, getting a tradable permit system underway at all is likely to pose a significant political challenge and in this respect it makes sense to start out with a limited system, as long as it will not prevent a more cost-effective solution to emerge later on.

Thus, as suggested by Varming et al. (2000), an EU permit market could, for a start, include all boilers larger than $25 \mathrm{MW}$, similar to the delimitation of the target group in the US Acid Rain Program. Table 1 shows the total number of boilers in the EU with different primary fuels. The total number of fossil-fuelled boilers in the EU amounted to 7038 in 1999, while the number of boilers larger than 25 MW amounted to 1690. The 1690 boilers are in the same order of magnitude as the US Acid Rain Program, 
which has proven to be a workable number. Secondly, the total number legal entities is reduced from 2959 to 375 while most of the installed capacity of fossil-fuelled boilers is still included in the market. As you can see, coal drops from 162 to 160, oil from 83 to 72 and gas from 75 to $66 \mathrm{GW}$. In other words, most of the emissions are still kept within the system. By doing this the administrative procedures can be developed and prepared for a larger scheme.

Table 1: Number of units and legal entities with different primary fuels in the EU, 1999.

\begin{tabular}{|l|c|c|c|c|c|}
\hline & Coal & Oil & Gas & $\begin{array}{l}\text { Fossil } \\
\text { fuelled } \\
\text { boilers } \\
\text { total) }\end{array}$ & $\begin{array}{l}\text { Legal } \\
\text { entities } \\
\text { (total) }\end{array}$ \\
\hline $\begin{array}{l}\text { Number of fossil } \\
\text { fuelled boilers }\end{array}$ & 916 & 2713 & 4280 & 7038 & 2959 \\
\hline $\begin{array}{l}\text { Installed capacity by } \\
\text { primary fuel, GW }\end{array}$ & 162 & 83 & 75 & - & - \\
\hline $\begin{array}{l}\text { Number of fossil } \\
\text { fuelled boilers > 25 } \\
\text { MW }\end{array}$ & 695 & 492 & 579 & 1690 & $\mathbf{3 7 5}$ \\
\hline $\begin{array}{l}\text { Installed capacity by } \\
\text { primary fuel, GW }\end{array}$ & 160 & 72 & 66 & - & - \\
\hline
\end{tabular}

Source: UDI database (2001) and Varming et al. (2000, 119).

\subsection{The risk of price manipulation.}

The crucial question is whether a $\mathrm{CO}_{2}$ market for these 375 companies will be competitive. Here, we need to consider the risk of price manipulation both in the permit market itself and from using the permit market to exclude competition in the product market of electricity (see Tietenberg 1985 and Svendsen (1998). Let us look at both possibilities in turn.

First, concerning price manipulation in the permit market, a dominating source (or a coalition of sources) may attempt to manipulate the price as a monopolist or a monopsonist. This market power depends on the firm's size relative to the market in which it is operating. If the dominating source offers too few permits, it can exert monopoly power by raising the price. If the dominating source buys too few permits, it can exert monopsony power by reducing the price. In both cases, the source may achieve a net gain at the expense of the cost-effective outcome.

The risk of price manipulation in the permit market and the strategic interaction can be assessed by using an $m$-firm concentration ratio. This index simply adds up the $m$ highest market shares in the industry and the risk of price manipulation is simply expected to increase with higher market shares, see Tirole (1990). 
We have found the following result for the electricity sector in the EU:

Table 2: Market shares for the EU power sector in the electricity market and the $\mathrm{CO}_{2}$, market, 1996/1997.

\begin{tabular}{|l|c|c|c|}
\hline & $\begin{array}{l}\text { Electricity market } \\
\text { shares }\end{array}$ & $\begin{array}{l}\mathrm{CO}_{2} \text { market shares } \\
\text { (electricity producers) }\end{array}$ & $\begin{array}{l}\mathrm{CO}_{2} \text { market shares } \\
\text { (emitters) }\end{array}$ \\
\hline $\mathrm{R}_{5}$ & $\mathbf{3 8 \%}$ & $\mathbf{2 5 \%}$ & $\mathbf{3 4} \%$ \\
$\mathrm{R}_{10}$ & $51 \%$ & $40 \%$ & $44 \%$ \\
$\mathrm{R}_{15}$ & $58 \%$ & $43 \%$ & $49 \%$ \\
\hline
\end{tabular}

Source: Company data collected from 1997 Annual Reports and Environmental Reports. Total production and emission figures from 1996 calculated from IEA Electricity Information 1997 and 1998 edition, see Varming et al. (2000).

Table 2 shows that the five largest companies (legal entities) have an electricity market share of $38 \%$ and are responsible for $25 \%$ of the $\mathrm{CO}_{2}$ emissions. Furthermore, the five largest $\mathrm{CO}_{2}$ emitters have a $\mathrm{CO}_{2}$ market share of $34 \%$. Even though such an index is at best only indicative of the possibility of market power being present in the $\mathrm{CO}_{2}$ market, the numbers indicate that the electricity sector is indeed suitable as a starting point for emissions trading.

Second, the risk concerning strategic interaction between these two seemingly competitive markets must be considered. The incentive to exclude competitors in the product market by keeping them out of the permit market may cause monopolistic behavior as a source - or a group of sources - may refuse to sell permits to new entrants and thereby create a barrier to entry, i.e. a cost of production. This extra cost must be borne by a firm which seeks to enter an industry but is not borne by firms already in the industry' (Stigler , 1968:67). Such a 'predatory' source may in this way increase its opportunities for manipulating the price in the product market (Tietenberg 1985: 138). This behaviour must be considered here as the two engaging sources are direct competitors in the same product market (electricity), emitting the same pollutant $\left(\mathrm{CO}_{2}\right)$ in the same regulated area (European Union).

The risk of possible strategic interaction between the output market and permit market is depicted in Figure 1. Here, the electricity market shares as well as the $\mathrm{CO}_{2}$ market shares for the larger power companies in the EU are shown. 
Figure 1: Product and $\mathrm{CO}_{2}$ market shares for the larger power companies in the EU.

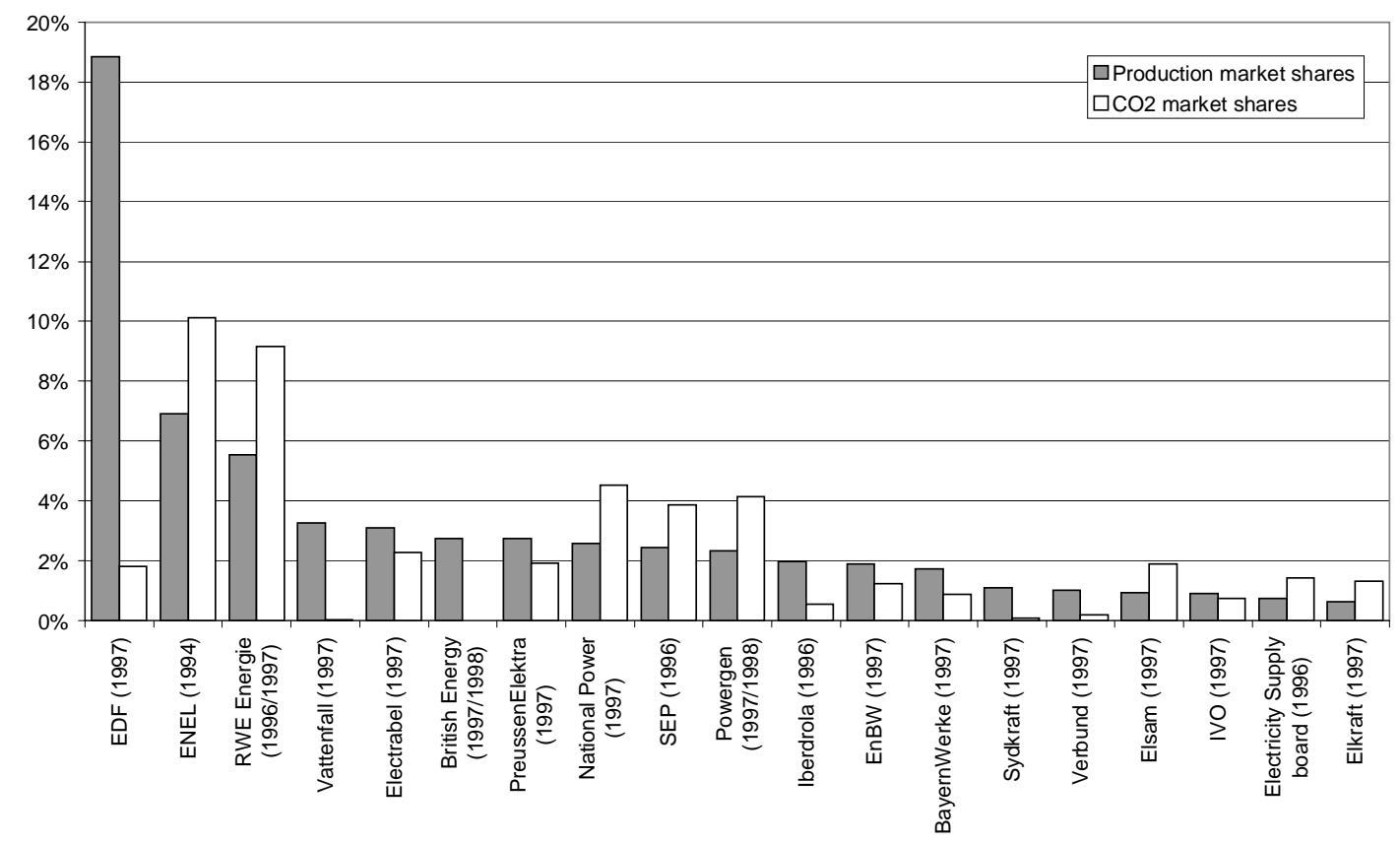

Note: $\mathrm{CO}_{2}$ market shares have simply been calculated as the percentage of total $\mathrm{CO}_{2}$ emissions from power production that stems from individual power companies.

Source: Company data collected from 1997 Annual Reports and Environmental Reports. Total production and emission figures from 1996 calculated from IEA Electricity Information 1997 and 1998 edition, see Varming et al. (2000)

Figure 1 shows, that the largest companies, are not among the highest emitters of $\mathrm{CO}_{2}$, e.g. the EDF is the largest electricity producer but is one of the smallest $\mathrm{CO}_{2}$ emitters. Thus, the fact that the electricity producers holding the largest production shares are different from those holding the largest $\mathrm{CO}_{2}$ shares also suggest, that the electricity sector can form the basis of a competitive $\mathrm{CO}_{2}$ market in the EU. In other words, the EDF cannot, as a small $\mathrm{CO}_{2}$ emitter influence the entry to the electricity market by refusing to sell $\mathrm{CO}_{2}$ permits to a potential competitor; it is easy for the competitor to buy the needed $\mathrm{CO}_{2}$ permits from other emitters that are small in the electricity market.

After initiating a $\mathrm{CO}_{2}$ market for the EU electricity sector, the administrative procedures can, if the market works, be developed and prepared for a larger scheme. In the long run, it should, as is the case in the US Acid Rain Program, be possible for other $\mathrm{CO}_{2}$ emitters to opt-in and join the market if it pays them, e.g. a larger industrial plant may take advantage of such a rule (Svendsen, 1998). Overall, we suggest that it will be possible to reduce the number of boilers to 1690 and still keep most of the emissions in the system and still keep the market competitive.

However, the electricity sector should not be seen in a static perspective. The changing frame conditions following the liberalisation directive for the electricity and gas sectors have started to provoke a response from the industry itself. It seems clear 
that the size of a company is a shaping factor with regard to the type and dimension of risks that can be accepted and the ability to expand into new markets and businesses clearly depends hereon. So far, we have seen a tendency towards horizontal integration between power companies as well as power companies buying up distribution companies. Within the last few years, several of the larger companies in have merged (or have announced plans to do so). This is true for $\mathrm{EdF} / \mathrm{EnBW}$, PreussenElektra/Bayernwerke and RWE/VEW. This process is expected to proceed and the result will probably be only a handful of large companies within a relatively short period of time.

Furthermore, the fact that electricity has to be supplied via a grid makes the competitive situation quite unique. As there are no economically viable storage opportunities for electricity, supply has to equal demand at all times. This is coupled with the fact that the flow of electricity in a grid is governed by the law of physics and cannot be allocated in a certain direction. Thirdly, the power loss in a grid rises quadratically with the current and linearly with the distance. What all this means is that the competitive situation of a specific power plant can change dramatically during the day, week or year. At some hours the power plant may be exposed to competition by a range of other suppliers while at another time of day the competitive situation may be more like a local monopoly.

The transmission capacities and the way the usage of this transmission capacity is priced determine the extent to which a Danish power plant will compete with a Dutch power plant. Even though a system with free third-party access to the transmission grid is established, securing that future investments in the transmission grid will actually reflect the scarcity in the grid can also be a potentially contentious issue, especially with regard to the building of international transmission capacity. However, as long as primary energy is by large cheaper to move around than electricity, there will be no need for moving around a substantial volume of base load electricity from the southernmost part of the EU to the northernmost part.

\section{3: Allocation}

In terms of allocation, we simply suggest that each electric utility gets the right to match its 1990 emissions for nothing, that is the permits would be 'grandfathered'. Permit allocation would then be defined according to the nominal Kyoto emission target levels starting in 1990. Utilities established after 1990 could be eligible for a free, initial standard distribution, if they apply before a certain deadline (Svendsen 1998). Whether the electricity sector in a country should take over the same percentage reduction as its country is a more open question. E.g., Denmark is obligated to reduce GHG by $21 \%$ meaning that its electricity sector would have to take over the same $21 \%$ reduction obligation. In contrast, e.g. Sweden is allowed to increase its GHG emissions by 4\%. Such a 'take-over' approach may therefore distort competition in a single market for electricity. Still, as the electricity sector dominates domestic GHG emissions anyhow, we suggest that the starting point for further EU negotiations should be that a sector 'takes over' the national target level. 
Each legal entity in the electricity sector will then receive individual permits, each giving the right to emit e.g. 1 tonne of $\mathrm{CO}_{2}$. Each permit will specify the year of issue (vintage year) and once the permit has been used to show compliance it will be withdrawn from the market. The duration of the compliance period is set to one year. Note, that the entitlement is not a full property right but rather a limited permission to emit $\mathrm{CO}_{2}$. This approach has also been used in the US and it allows the government to make changes over time without any compensation to the market participants (Svendsen, 1998). Obviously, any changes in the entitlement to $\mathrm{CO}_{2}$ permits have to be done with extreme caution, since a full property right is essential for a well functioning market. Thus, it is important that a credible economic value of $\mathrm{CO}_{2}$ permits is established for a considerable time period reflecting the long investment horizons in the power sector. Any alterations in the overall allocation of permits to the permit market must be the economic responsibility of the EU and not the market participants. E.g., the EU must buy up permits in the market to reduce emission levels further so that extra costs are not suddenly imposed on market participants. To maximise flexibility in the market, the system should allow for unlimited banking of permits as well.

Finally, concerning allocation of the GHG permits, we propose that the EC should undertake a yearly EU-wide auction where all or a large share of the permits are put out for sale. The inclusion of a large share of the permits, e.g. $10 \%$ of all permits in circulation, in the auction will secure equal access to the permits in all the Member States and thus an efficient allocation of the permits. Furthermore, this will provide price information and transparency to the market, which is important especially in the beginning when market participants are not that familiar with the market (Christensen and Svendsen, 1999).

We propose to use a non-discriminatory pricing principle for the auction where all bidders of permits pay the clearing price for the permits (provided that their bid was below the clearing price). The non-discriminatory auction provides important information to the market and works fine except in the case of a few very dominant market actors ${ }^{1}$. The revenue from the auction is redistributed to the legal entities according to the overall distribution of responsibilities that is decided upon. The actual redistribution of the revenue to market participants could be left to the discretion of Member States with regulatory oversight by the Commission.

To make sure that there are buyers as well as sellers in the permit market and that the risk sharing capabilities of the marketplace will come into play, everybody should be allowed to participate in the market. Obviously, this includes brokers and traders as well. Brokers will offer arrangements (bilateral contracts) that hedge the price risk of buyers and sellers in the permit market. Experience from the US $\mathrm{SO}_{2}$ market have shown that contracts that address the volume risk directly and not necessarily the

\footnotetext{
1 Neither a non-discriminatory (uniform) pricing principle nor a discriminatory ("pay-your-bid") pricing principle is fully efficient because it can be shown that bidding your true demand curve is dominated by other strategies. If market power is not significant, the uniform pricing principle is nearly efficient (See Cramton \& Kerr, 1998).
} 
price risk are likely to be introduced, i.e. weather hedges. Traders (or speculators) on the other hand, take open positions in the permit market and speculate in future price changes. This adds liquidity to the market and reduces the difference between bids by buyers and sellers. Like in the US the system could start before the first compliance period. Possibly, the regulators should also release permits that are valid in the current year as well as permits that are valid in years to come (i.e. selling vintage year 2008 permits and vintage year 2013 permits at the same time) (Varming et al 2000: 122).

\section{4: Mix of instruments}

Monitoring and enforcement costs are likely to be too high to make it worthwhile to include all smaller polluters. All plants or households that are not included in the market should be regulated by a tax or some other measure to ensure that they are faced with approximately the same cost per unit of emissions. Also, if monitoring costs are found to be too large for some smaller industrial plants these should be regulated by a tax or some other measure to ensure that they are faced with approximately the same cost per unit of emissions.

Green taxation in relation to small polluters is not only the right solution for economic reasons. Also political reasons point strongly to the proposed mix of economic instruments where a grandfathered permit market is used in relation to big polluters and green taxation is used in relation to small polluters. Svendsen et al. (2001) shows how big and well-organized industrial plants successfully has lobbied against green taxation, whereas small polluters, such as consumers, have been less successful. The large group of households has difficulties to organize because the net benefits for individual household action are negative; it does not pay to take initiative and organize the whole group for collective action and capture the total net benefits. Therefore, due to weak lobbying power, households are presumably taxed much higher than the well-organized and strong industry lobby. With a large difference between the $\mathrm{CO}_{2}$ tax rate applicable to the households and the one applicable to the industry in the OECD countries, it is clear that considerations of the effect on industry has been taken into account when formulating the environmental policy. On average over the five cases, households are met with a tax rate four times higher than that of the industry, and further, if the tax advantage of the industry is included, it increases to six times the size. This indicates that the empirical findings confirm the theoretical conclusions on organized interest groups influencing the tax policy decisions (ibid.).

A permit market, on the other hand, is politically more attractive to the organized polluters than a tax scheme due to the possibility of a free, initial distribution (grandfathering). Here, Daugbjerg and Svendsen (2001) derived a formula for the distributional effects of these two economic instruments. It showed that for target levels, such as the Danish case of a $20 \% \mathrm{CO}_{2}$ reduction or the EU case of $8 \% \mathrm{CO}_{2}$ reduction, the tax solution (without refund) was nine and twenty-four times more costly for polluters respectively than the grandfathered permit market, provided that the MC curves are linear. For large and influential polluters, such as the electric utility industry, this makes the grandfathered permit system a much more attractive environmental policy measure than green taxes (ibid.). 


\section{5: Enforcement}

The purpose of the control system is to make the whole trading scheme credible by assuring that there is a one-to-one correspondence between a permit to emit one tonne of $\mathrm{CO}_{2}$ and the actual emission of one tonne of $\mathrm{CO}_{2}$. Avoidance of cheating in the system is crucial to make it work. At present two monitoring mechanisms of national emissions exists (Varming et al, 2000: 134): First, a national reporting to the secretariat of the UNFCCC, and second, an EU monitoring mechanism.

The national reporting to the UNFCCC is at present a relatively slow reporting system giving a time lag of 1-2 years between the timing of emissions and reporting. Even though this reporting may be speeded up it will probably continue to be too slow to serve as market information.

Despite its modest and technical name, the 'EU monitoring mechanism' must be considered the cornerstone of the EU climate policy in the second half of the 1990s. Adopted in June 1993, it obliges member countries to develop national programs for reducing greenhouse gases while the Commission evaluates the data provided by the member countries. An important feature of the monitoring mechanism is that it introduces additional and more specified commitments than the FCCC. However, inadequate reporting by the member countries has so far reduced its effectiveness. (Ringius, 1999)

As Varming et al. (2000:18) argue, the emissions data can be collected by means of self-reporting by the companies. The most important role to be played by EC institutions will be to establish minimum requirements with regard to the measurement of emissions while to a large extent leaving actual monitoring and verification of emissions to the Member State Governments. The annual reporting of emissions from the power and steam sector must be faster than today. The final data for the preceding year should be available in January in order to allow for a true-up period for the emission rights. To give the best possible market information it is proposed to report and publish emission data for companies included in the trading scheme on a monthly basis. This will mean speeding up of the existing reporting procedures, but it should be possible to do this with only minor extra costs. Member States could then verify the emissions reported by companies on a yearly basis and submit their result to an EC institution. Obviously, the Member States might have incentives to cheat as well, however, the scope for cheating should be relatively small with respect to the power and steam sector.

Next, a central registry must be created at the EU level. This function can be computerised and should not give any theoretical or practical difficulties, which has been clearly demonstrated by the US Acid Rain programme. Data for emissions may be collected by national authorities but shall at once be transmitted to a European institution. Through the trading system, a registry of permit holdings of each of the actors in the market is established. Likewise, through the monitoring process, a 
registry of the actual emissions of each actor is established. The "trick" of the enforcement is to compare the two numbers for each actor and have the necessary authority to deter actors from breaking the emission limits.

First of all, we need to deter cheating by companies. Taking into consideration that the likelihood of detecting cheating is pretty high in this trading scheme, it will probably not be necessary with sanctions such as prison sentences to deter cheating. A high monetary sanction should be sufficient. The next step will be to establish sanctions against market participants exceeding their permit holdings. The suggestion here is straightforward. Market participants whose emissions are exceeding their current permit holdings must pay a fine for their excess emissions. The level of the fine must be the same in all Member States. Otherwise, there could be carbon leakage to areas with lower fine levels.

If the fine is kept very low, the emissions trading scheme will work very much like a price instrument (tax), whereas a high fine will secure that the emission target is reached (at any cost to society). Thus, a relatively low fine is proposed for the trading scheme, and the fine could be set in the neighbourhood of $40 \mathrm{EUR} / \mathrm{tCO}_{2}$ which is probably sufficiently well above the expected market prices (ibid). The fine payments could be used by the enforcement institution to buy emissions permits internationally, in order to secure that the overall emission target of the trading system is met (ibid.).

If emission trading is organised as proposed above with a single emissions target for all market participants, the issue of enforcement is 'reduced' to securing the individual compliance of all actors. Thus, in the context of a EU scheme of emissions trading it would be natural that the ultimate responsibility for ensuring compliance will be on a European level. One could argue that monitoring and enforcement in relation to the companies from the starting point will be a Member State task, because the Member State Authorities are equipped with the necessary regulatory power in relation to the private parties. On the other hand, the system could gain in general efficiency and credibility by the establishment of a common super-national European institution. It is important that the control system overall is administered by one single and central authority so that local authorities do not have the full control responsibility and as such are not tempted to protect their own firms. This could be the CEU (Commission of the European Union) which will have a bureaucratic selfinterest in handling the system and thereby get access to higher budgets.

The direct measurement of $\mathrm{CO}_{2}$ emissions is expensive. As noted by (UNCTAD 1995), it is also unnecessary since accurate estimates can be made on the basis of the volume of carbon-based fuels that are burnt. All that is required is therefore that the flow of fuels is being monitored. In terms of monitoring of emissions, calculating the $\mathrm{CO}_{2}$ emissions from the fuel input is a very cheap and efficient method and the scope for cheating will be low because there is a close relation between fuel input and electricity output for a given plant. Both amounts can be found in the financial accounts of the company, accounts that are verified by external auditors. 
Still, for coal fired plants a number of complications are involved in calculating the emissions from the fuel input. To estimate $\mathrm{CO}_{2}$ emissions from the content of carbon in the fuel it can be necessary to distinguish between coal of different origins as the carbon content can differ substantially. As an example, the yearly weighted average of $\mathrm{CO}_{2}$ emissions from the types of coal used by the Energy Company ELSAM is 95 grams of $\mathrm{CO}_{2}$ per MJ. The emissions from the different types of coal lie in the range of 87 grams of $\mathrm{CO}_{2}$ per $\mathrm{MJ}$ as is the case with coal from Canada and a maximum of 100 grams per MJ as is the case with coal from Great Britain. The variation in the yearly $\mathrm{CO}_{2}$ emissions per $\mathrm{MJ}$ from any particular power plant is low, though (lies within a range of $\pm 1 \%$ ). If the emissions were to be reported every month the resulting variation in $\mathrm{CO}_{2}$ emissions per $\mathrm{MJ}$ would be higher. This would make it practically harder to come up with a precise estimate of the $\mathrm{CO}_{2}$ emissions, since closer attention must be paid to what type of coal is actually being used at every given point in time. This is not always obvious, as different types of coal usually get mixed when lying on a storage yard. It also must be taken into account that part of the coal is left unburned in the ashes. This share varies between individual plants depending on the design. For pulverised coal firing the typical fraction of unburned is $5 \%$, but within a range of 3-10\%. For grate firing the typical fraction of unburned fuel in the ashes is as high as 30-40\%. Grate firing is a technology that is 'dying', but a number of small, mainly industrial plants still exist. Finally, there is also a marginal emission of $\mathrm{CO}_{2}$ from limestone used for desulphurisation. (Varming et al., 2000: 133)

As described, there are a number of uncertainties that must be handled if fuel input shall be used to calculate $\mathrm{CO}_{2}$ emissions from coal fired plants. These uncertainties have to be weighted against the uncertainties of direct measurement. It is well known that it is quite easy to make very accurate measurements of the concentration of $\mathrm{CO}_{2}$ in a gas, but measuring the flow of flue gas is much more uncertain. Following another line of argument, (ABARE, 1998) notes that it would be desirable to base required permit holdings on a direct measurement of emissions since technologies are being developed for the post combustion capture and disposal of carbon dioxide emissions. However, these technologies are far from being economical at the moment due to large energy and investment costs. The argument is thus not very strong.

In conclusion, calculating the $\mathrm{CO}_{2}$ emissions from the fuel input is a very cheap and efficient method. This will be relevant for many of the smallest installations and thus not put a lower limit to the size of plant that can be part of the trading scheme. For coal fired plants the uncertainties can be so large that direct measurement should be preferred. These installations are usually large and the extra costs for measurement of $\mathrm{CO}_{2}$ emissions will be of minor importance. As long as the levels of uncertainties are comparable (in fact, as long as the uncertainties are not biased so that they sum out over time), the use of different methods of measuring will pose no difficulties.

\section{6: Policy recommendation}

Our research question was stimulated by a gap in the literature on how to design greenhouse gas permit trading in the EU. This is important if the EU is to accomplish 
its stated 8\% reduction target level following the Kyoto Protocol. Our policy recommendations concerning the four main design issues in the Green Paper by the Commission of the European Union, are summarized in Table 3.

Table 3: Policy recommendation concerning $\mathrm{CO}_{2}$ trading in the European Union.

\begin{tabular}{|c|c|}
\hline Design & \\
\hline 1. Target Group & $\begin{array}{l}\text { The electricity sector should initially be allowed } \\
\text { to trade } \mathrm{CO}_{2} \text { emissions. This points to a } \\
\text { competitive market consisting of } 375 \text { agents } \\
\text { (legal entities) where no single firm seems } \\
\text { capable of manipulating the permit price nor } \\
\text { using the permit market as a barrier to the product } \\
\text { market of electricity. If the system works, major } \\
\text { industrial firms may opt-in. }\end{array}$ \\
\hline 2. Allocation & $\begin{array}{l}\text { Electricity sector 'takes over' the national target } \\
\text { level and gets its } 1990 \text { emission levels for free } \\
\text { (grandfathering). The GHG permits are defined in } \\
\text { terms of one year and the EU has the economic } \\
\text { responsibility concerning possible future } \\
\text { reductions. Also, an annual, revenue-neutral } \\
\text { auction, where } 10 \% \text { of the permits in circulation } \\
\text { are sold, should be linked to the market. }\end{array}$ \\
\hline 3. Mix of Instruments & $\begin{array}{l}\text { Grandfathered permit markets should be used in } \\
\text { relation to big and well-organized polluters (such } \\
\text { as the electricity sector) whereas green taxation } \\
\text { should be used in relation to small and badly } \\
\text { organized polluters (such as small firms and } \\
\text { households). }\end{array}$ \\
\hline 4. Enforcement & $\begin{array}{l}\text { Self-reporting by the companies to member states } \\
\text { surveyed by a supra-national authority could be } \\
\text { an appropriate way to collect emissions data. The } \\
\text { Commission of the European Union could be this } \\
\text { authority independent from local interests and in } \\
\text { charge of a central registry. It is technically } \\
\text { feasible to calculate } \mathrm{CO}_{2} \text { emissions from the fuel } \\
\text { input in a cheap and efficient way. The fine for } \\
\text { cheating could probably be set at the level of } 40 \\
\text { EUR/tCO } \mathrm{CO}_{2} \text { which is likely to be sufficient to deter } \\
\text { potential defectors in the system. }\end{array}$ \\
\hline
\end{tabular}




\section{Literature}

ABARE (1998), International Climate Change Policy - Impacts on the European Union, Research

Report 97:9, Canberra.

Baumol, W.J. and Oates, W.E. (1988): The Theory of Environmental Policy, 2. ed., Cambridge University Press, New York.

CEU (2000a): Green Paper on greenhouse gas emissions trading within the European Union. Commission of the European Communities, Brussels, 8.3.2000, COM (2000) 87 final.

CEU (2000b): Communication from the commission to the council and the European parliament - on EU policies and measures to reduce greenhouse gas emissions: Towards a European Climate Change Programme (ECCP). COM (2000) 88 final, Brussels 8.3.2000.

Cramton, P.; Kerr, S. (1998), Tradable Carbon Permit Auctions. How and why to auction not

grandfather, University of Maryland. Discussion paper. Resources For the Future.

Daugbjerg, C. and Svendsen, G.T. (2001): Green Taxation in Question. MacMillan (Palgrave), UK.

Dijkstra, B.R. (1999), The political economy of environmental policy. New Horizons in Environmental Economics, Edward Elgar, Cheltenham, UK.

EU (1999): EU's Annual Energy Review. Brussels.

Ringius, L. (1999), The European Community and Climate Protection - What's behind the empty

rhetoric?, Center for International Climate and Environmental Research (CICERO), Report 1999:8.

Stigler, G.J. (1968), The Organisation of Industry, Richard D. Irwin, Homewood.

Svendsen, G.T. (1998): Public Choice and Environmental Regulation: Tradable Permit Systems in United States and $\mathrm{CO}_{2}$ Taxation in Europe. New Horizons in Environmental Economics, Edward Elgar, Cheltenham, UK.

Svendsen, G. T., Christensen, J. L. (1999). The US $\mathrm{SO}_{2}$ auction: analysis and generalisation. Energy

Economics Vol. 21(5), 403-416.

Svendsen, G.T.; Daugbjerg, C.; Hjoellund, L. and Pedersen, A.B. (2001): 'Consumers, Industrialists and the Political Economy of Green Taxation: $\mathrm{CO}_{2}$ taxation in OECD.' Energy Policy. 29 (6), 489-97. 
Tietenberg, T.H. (1985): Emissions Trading: An Exercise in Reforming Pollution Policy. Washington, D.C.: Resources for the Future.

Tietenberg, T.H. (2000): Environmental and Natural Resource Economics. Fifth Edition, Addison-Wesley.

Tirole, J. (1990), The Theory of Industrial Organisation, The MIT Press.

UDI database (2001): "World Electric Power plants Data Base", Platts Utility Data Institute: Update June 2001.

UNCTAD (1998) Greenhouse Gas Emissions Trading - defining the principles, modalities, rules and guidelines for verification, reporting \& accountability, Draft, July 1998.

Varming, S.; Eriksen, P. B.; Grohnheit, P. E.; Nielsen, L.; Svendsen, G. T.; Vesterdal, M. (2000), $\mathrm{CO}_{2}$ permits in Danish and European energy policy. Ris $\emptyset$. R-1184(EN). Ris $\varnothing$ National Laboratory, Roskilde, www.risoe.dk/rispubl/SYS/ris-r-1184.htm.

Wallart, N. (1999), The Political Economy of Environmental Taxes. New Horizons in Environmental

Economics. Cheltenham, UK: Edward Elgar. 